\title{
THE EVOLUTION OF INTERNATIONAL WATER LAW*
}

\author{
PAULO CANELAS DE CASTRO \\ Faculty of Law, University of Macau
}

\begin{abstract}
International Water Law has been witnessing deep changes in the latter two decades. These changes denote certain cardinal options for new values that the newer International Water Law is seeking to embrace. Amongst these, the ones of environmentalization, humanization and economicization stand out as attempts at bringing efficient response to the challenges set by the current global water crisis. They amount to true paradigm shifts in the understanding of International Water Law and the normative message conveyed.

Keywords: economicization, environmentalization, humanization, human right to water, International Water Law, paradigm changes, trade in water, water protection, water services.
\end{abstract}

\section{INTRODUCTION}

After a few decades of a rather lethargic state, corresponding to the attempt at codifying it undertaken, particularly, by the International Law Commission [1,2] and marked by a rather schizophrenic debate over the prevalence of the following two water sharing principles, simplistically seen as competing (those of the equitable and reasonable use of international watercourses and the obligation not to cause damage, also known as the no harm principle), International Water Law has been witnessing a considerable normative development in the latter two decades.

This normative development may be detected in multiple signs. Foremost, in the frantic law-making endeavors permeating international life: most noticeably, those translated in the adoption of numerous treaties at the different ambits of the international society; but also in, the not less significant, soft law, undertaken in particular by manifold international organizations or conferences, which, in the period, have brought water issues to the forefront of the global international agenda. Additionally, also in the several international disputes, in which water is invoked as the main subject matter and the unprecedented swathe of decisions, which take water and International Water Law as their casus decidendi and rationale.

This hectic normative development is, moreover, of a much diversified character. Mirroring trends that had already been at the origin of the formidable development of International Law at large, more broadly over the last seven decades, and which had led a leading scholar to adroitly proclaim the postontological hour of International Law [3], it seems arguable that this progress has in general been happening by cross-fertilizing the traditionally rather impermeable body of International Water Law with other fields of International Law [4,5]. This global trend towards the corpus iuris of International Water Law building bridges with other fields of International Law - namely, International Environmental Law, International Law of Human Rights and International Economic Law - may therefore be summarily apprehended in three main substantive 'friendships' or 'leanings' of International Water Law, its newer value or teleological choices: a choice towards 'naturalizing', 'environmentalizing' or 'greening' International Water Law; a trend towards 'humanizing' International Water Law or, more broadly, rendering it more inclusive; and, more recently, a leaning towards looking more attentively at water, and the International Law which is related to it, through a more consciously economic angle.

* This is the extended version of the Keynote Address delivered by Professor P. Canelas de Castro at the International Water and Society Conference, held in A Coruna, Spain, at which he was awarded the Eminent Scientist 2015 Medal.

(C) 2015 WIT Press, www.witpress.com

ISSN: 1743-7601 (paper format), ISSN: 1743-761X (online), http://www.witpress.com/journals DOI: 10.2495/SDP-V10-N6-894-900 


\section{THE ENVIRONMENTALIZATION OF INTERNATIONAL WATER LAW}

The environmentalization of International Water Law passes first through the normative apprehension of the reality of water bodies as it really happens: in its multiple interconnections and unitary complexity - of (non-confined) groundwater with surface water, of the watercourses with other biota and ecosystems, with the land mass as well as with marine waters. Several legal documents advocate that catchment areas or other analogous integrating concepts be used as the water management units. This then permits and facilitates a more realistic or effective legal discipline: one where development of water is not any longer the sole goal pursued, but development becomes integrated with the goal of protection of water; one where, therefore, only sustainable development is lawful. Protecting the environment or ecosystems of watercourses, water quality, as well as the fight against diverse forms of pollution, thus become main concerns and normative areas of the newer international water legal disciplines. Correspondingly, the scope of the obligations comprehended is equally enlarged: beyond obligations of mitigation and minimization or reduction and control of harm - of risks, even - there are now obligations of prevention of impacts, of precaution. They all explain the consecration of procedural duties, ranging from notification of planned measures to consultations and negotiation, from simple obligations of access to information to a general duty to perform environmental and strategic impact assessments, sometimes $e x$ post even. This wider approach becomes the more necessary as one acknowledges the crucial relevance of water in the ongoing conditions of scarcity [6] and climate change [7]. Both realizations call for actions and measures that have a broader and cyclical time reference. These developments are in line with the concept of integrated water resources management as defined by the Global Water Partnership and are based on the 1992 Dublin Statement on Water and Sustainable Development.

\section{THE HUMANIZATION OF INTERNATIONAL WATER LAW}

International Water Law has equally been witnessing a move towards including more legal personae within the remit of participating legal subjects.

This move concerns its traditional legal subjects, first: the States, the riparian States. Increasingly, the new International Water Law advocates that all those States, riparian to a particular shared watercourse, participate in the corresponding legal discipline, thus matching at this level an effort at ensuring that the said legal discipline corresponds to reality, and that it therefore may prove more efficient. Moreover, in a few instances, International Law equally calls on the participation of coastal States adjacent to the riparian ones, in a legal development which again evidences an attention to natural reality and the real dynamics of impacts.

Secondly, the newer International Water Law equally concerns intergovernmental organizations and institutions of very different structures and functions [8,9]. Their establishment or revival reflects the perceived need of States to enhance cooperation to manage shared water resources over several territories. Their existence facilitates the recurring dialogue between the riparian States as to the activities that each of them purports to promote within its jurisdiction, particularly with regard to the sharing of rights and benefits deriving from the development of the waters as well as the prevention, reduction and control of risks of damages. They especially allow for an institutional process of communication, made of different procedural acts which permit the assessment of the effects of planned or existing measures or projects. Finally, they also enable the carrying out of joint activities.

Most noticeably, different legal instruments recommend that river/watercourse commissions be set up or that their experience is used in the daily effort of not only implementing but also developing primary regimes. In some cases, international organizations or international commissions are equally 
called to complement the action of the States (by providing financial and technical assistance, or working as instances for the prevention and settlement of disputes).

Additionally, these organizations and institutions are sometimes also the platform for other non-governmental actors to intervene; like environmental, human rights' or governance NGOs, as well as epistemic communities, companies and individuals. All of them, thus thereby find their way to voice their concerns, grievances, interests, information and expertise. Simultaneously, they obtain some legal status in the processes of decision-making or adjudicating the manifold issues of water management.

The whole movement reaches its climax once International Law engages into its humanization first, by recognition of procedural rights of access to information, participation in decision-making and in administrative decisions relating to the environment as well as the judicial appeal against such decisions, and rights of participation in impact assessments as well as in the aforementioned institutional water platforms. The 1998 Aarhus Convention on access to information, public participation in decision-making and access to justice in environmental matters, in the UNECE universe, stands out in such context as a prominent illustration.

The humanization of International Water Law is evidenced then in the adoption of a human right to water and sanitation [10], which corresponds to the satisfaction of the most basic human needs and overcomes a blatant lacuna of the International Bill of Human Rights. Initiated with General Comment no. 15 of the Economic and Social Council, the process of consolidation of such double right gained momentum in 2010, by the adoption of corresponding resolutions by the General Assembly of the United Nations (Resolution 64/292 of the UN General Assembly, 'The Human Right to water and sanitation', UN Doc A/Res/64/292 , of 3 August 2010) and the Human Rights Council (Resolution 15/L.14 of the Human Rights Council, 'Human rights and access to safe drinking water and sanitation', UN Doc A/HRC/15/L.14 of 24 September 2010). These documents mainly anchor such rights of multifaceted content in the remit of economic, social and cultural rights - a qualification, which renders these rights ones of a progressive realization. Besides, it equally implies a certain number of consequential obligations for the States, namely obligations to respect, protect and fulfill. Amongst other duties, they call for the States' supplementary regulatory work. It is equally certain that the human right to water does not hinder the State to perceive payment for the services rendered. This applies, moreover, to not only the State, but also other actors, which may, in particular, intervene in the provision of water services or waste treatment services. This intervention seems justifiable: not only because the right is neutral as to the economic model adopted by the State as to such vital public services, but also because momentous investments seem indeed to be in order for rendering this proclaimed right a true reality. In any event, the interface between this right and a kind of water management more economically driven is, doubtlessly, one of the areas where International Water Law may need further development and clarification.

\section{THE INTEGRATION OF THE ECONOMY AND ITS DISCIPLINES}

The third vector of renewal of International Water Law contends with the integration of the economy and its disciplines. The departing point is parallel to the ones seen with regard to the aforementioned strands of evolution of this body of rules: besides being taken as an environmental good, and a pole for legally empowering a diverse host of actors and particularly for accrediting human rights, water is also more and more apprehended as a commodity, as an economic good.

This development is propitiated by several factors: the widespread awareness of water scarcity and unequal distribution, leading to a mounting demand for the resource as well as a rising capacity to dispose thereof over time and space. 
Such developments then lead to elucubrations whether water or the service of its provision gains in being set in a market context, attached a 'rationalizing' price tag [11,12]. It is equally questioned whether there is merit in trading bulk water [13] besides increasingly conveying it across space from 'water-rich' to 'water-poor' areas (examples include the tender between Turkey and Israel, the export of water from Canada to the USA, the transfers between Malaysia and Singapore, Lesotho and South Africa, Mainland China to Hong Kong and Macau [14,15]), as well as collecting it from the natural milieu, bottling it and selling it in a growing market of water 'products' [16]. This approach is epitomized in some policy documents from the 90s of last century, like the Agenda 21, the Dublin Declaration or the World Water Vision of the World Water Council.

Similarly, an apparently growing stream of legal thinking seems to be devoted to wondering whether there may be merit in applying International Trade Law (and the WTO agreements, GATT and GATS foremost [17-19]) as well as International Investment Law (the myriad of regional agreements and BITs), as well as the corresponding institutions, to relevant water operations and what may be the consequences of such course of action.

More specifically, this rather creative or 'outside-the-box' legal thinking is concerned, first, with regard to the trading of bulk water products, whether water may be treated as a 'good', a 'product'. It wonders, next, whether there is anything specific to water, justifying, if not imposing, that these principles governing international trade be derogated (the principles of most favored nation, of non-discrimination) or instead that it compels certain water-rich countries to envisage exporting water resources in abundance. Were the GATT disciplines deemed to be applicable, another line of enquiry is what would the margin of maneuver for an exporting State mindful of the necessity to follow a precautionary approach in the management of its water resources be, so as to avoid violating GATT obligations aiming both at reducing tariff barriers and quantitative restrictions on trade as well as to remove any national measure that discriminates against domestic products vis-à-vis imported products; whether in its managerial policies of environmental protection or driven by social considerations, such State could be comforted in the excepting clauses of Article XI. 2(a) and, particularly, Article XX of GATT (especially, (b) and (g)). Equally, it is asked whether it would be sensible to depend on the adjudicatory mechanisms of the WTO dispute settlement system for pursuing such policies.

With regard to water and wastewater services and the applicability of GATS, the main queries regard, besides classification issues, the possibility of carving out water public services in case of opening up the market to other foreign or domestic service providers. Alternatively, it seems important to assess the usefulness of the reasons that article XIV of GATS provides, permitting derogations from the State's specific commitments, and, more largely, the extent of regulatory powers, which the host State may safeguard in the name of the pursuance of the public interest. Another provision with relevance is Article XIII of GATS, which sets out that the obligations of most favored nation treatment, market access and national treatment do not apply to 'laws, regulations or requirements governing the procurement by governmental agencies of services purchased for governmental purposes and not with a view to commercial resale or with a view to use in the supply of services for commercial sale'. If the contracts between public authorities and private water companies can be characterized as 'government procurement', then the GATS regime (the obligations of most favored-nation, market access and national treatment) does not apply either. It does not seem, however, that the concession contracts or build-operate-transfer contracts that are frequently used for ensuring water services should be considered public procurement.

In substantive connection to such debate, albeit not in terms of the legal instruments at stake, appear the discussions on investment solutions in the water sector. They derive from the apparent growing recognition of the financial crisis of the State. This financial crisis leads the State to rethink 
the priorities and engagement in the economic sector and, in particular, in the water area, towards catering technical expertise and financial assets through multiple forms of privatization of services which had previously axiomatically been seen as public - namely by engaging sometimes very powerful multinational enterprises willing to offer such services on an economic profit logics; as it drives the State to opening up to foreign direct investment, usually protected by the body of rules of International Investment Law and its mechanisms of dispute settlement, often relying on international arbitration. In spite of its close proximity, whereas the former debate on market liberalization systematically pertains to WTO Law instruments and the GATS regime in particular, this latter one, for the lack of an investment dimension in the WTO agreements, rather has its systemic legal 'seat' in the area related to the hundreds of regional and bilateral investment treaties.

The main issue debated relates to the host State's regulatory powers in view of the obligations to protect international investment and the mechanisms for the State to protect public interest with regard to private sector participation in the economic management of water. The effort is at striking the right balance between the powers seeking the protection of public interest and serving corresponding obligations like those pertaining to a human right to water or those related to the protection of the environment, on the one hand, and those directed at the protection of international investments, on the other hand. A number of awards through ICSID dispute settlement (namely, in the Aguas del Tunari $v$ Bolivia ICSID Case No. ARB/02/3, in the Suez, Sociedad General de Aguas de Barcelona SA and Vivendi Universal SA v Argentine Republic ICSID Case No ARB/03/19, in the Biwater Gauff (Tanzania) Ltd v United Republic of Tanzania ICSID Case No. ARB/05/22 and in the Azurix Corp v Argentine Republic, ICSID Case No. ARB/01/12) may be viewed as indicative of progress in such direction [20].

\section{CONCLUDING REMARKS}

The protrayed newer leanings or trends of evolution of International Water Law reveal an effort at holistically apprehending and giving normative response to a more complex reality of problems and social expectations than those that used to be addressed by the old International Water Law, centered on the pure regulation of the uses of water. The changes involved are diverse and numerous. It seems, however, possible to identify some common threads underlying all the changes and trends identified. A first one is the move towards establishing a creative interface between the traditional core of this body of principles and rules dedicated to water and those other disciplines of International Law, which more directly address the concerns with the protection of the environment, social equity and a sensible weighing of the economic values. Internormativity is thus one of the keys for understanding the evolution of International Water Law and the vigor thereof; the normative dialogue generates cross-fertilization and renovation of International Water Law. Another one is the implicit sense of urgency that these proposed changes and trends carry, corresponding only to the magnitude of the global water crisis. These changes are definitely momentous, as the newer Law became much more complex in the normative responses pursued. They are not, however, deprived of an underlying vision: on the contrary, the newer International Water Law announces decisive cardinal options, pursues shared goals, honors certain values and follows principles that lend heuristic and interpretative sense to the reconstruction of this legal field. On the whole, the changes thus amount to true paradigm shifts. But this realization also alerts us to the uncertainties that are still involved in the progress of International Water Law. It is of the very nature of paradigm shifts themselves that they comprehend ambiguities and even elicit resistance. The uncertain harmonization of the trends for environmentalization and humanization of water, on the one hand, and its economicization, on the other, is in this regard telling. To this, one should add the realization that these developments are an ongoing process: new problems seem already 
perceptible in the horizon - 'climatizing' International Water Law, adapting it to the challenges of climate change seems to be one of them. Another one is the struggle to render the whole movement of 'legalization' or of more and newer law-making, a living reality: ensuring that the newer normative messages are complied with, should also become one of the major tenets of the evolution of International Water Law. Assessing the past but also looking ahead, one cannot but be reminded of the works of Sisyphus.

\section{REFERENCES}

[1] Tanzi, A. \& Arcari, M., The United Nations Convention on the Law of International Watercourses: A Framework for Sharing, Kluwer: London, 2001.

[2] McCaffrey, S., The Law of International Watercourses - Non-Navigational Uses, 2nd edn., Oxford University Press: Oxford, 2007.

[3] Franck, T.M., Fairness in International Law and Institutions, Oxford University Press: Oxford, 1995.

[4] Canelas de Castro, P., Recent Developments in International Law. Principles and Comparative Cases, Luso-American Foundation: Lisbon, 2005.

[5] Canelas de Castro, P., The global challenge of sustainable water management: International and European Union Law Responses. Temas de Integração, 25(1), pp. 95-133, 2008.

[6] Brown-Weiss, E., International Law in a Water Scarce World, The Hague Academy of International Monographs, vol. 7, Brill: Leiden, 2013.

[7] Canelas de Castro, P., Climate change and water management: is Water Law adapted to climate change? Water Resources Management VI, eds. C.A. Brebbia, V. Popov, WIT Press: Southampton, pp. 827-839, 2011. doi: http://dx.doi.org/10.2495/wrm110741

[8] Caflisch, L., Règles générales du droit des cours d'eau internationaux. Recueil des Cours de l'Académie de La Haye, 219(VII), pp. 196-202, 1989. doi: http://dx.doi.org/10.1163/ ej.9780792321408.009-225

[9] Boisson de Chazournes, L., The role of diplomatic means of solving water disputes: a special emphasis on institutional mechanisms. The PCA/Peace Palace Papers, Resolution of International Water Disputes, ed. The Permanent Court of Arbitration, Vol. 5, Kluwer: The Hague, pp. 91-110, 2003.

[10] Albuquerque, C., Water and sanitation are human rights: why does it matter? International Law and Freshwater: The Multiple Challenges, eds. L. Boisson de Chazournes, L. Leb, M. Tignino, Edward Elgar: Cheltenham, 2013.

[11] Cossy, M., Le statut de l'eau en droit international économique. Principaux aspects au regard des règles de l'Organisation mondiale du commerce. Les ressources en eau et le droit international, eds. L. Boisson de Chazournes, S.M.A. Salman, Martinus Nijhoff: Leiden, pp. 170-178, 2005. doi: http://dx.doi.org/10.1163/ej.9789004137028.3-756.5

[12] Hildering, A., Water as an economic good. Les ressources en eau et le droit international, eds L. Boisson de Chazournes, S.M.A. Salman, Martinus Nijhoff: Leiden, pp. 220-225, 2005. doi: http://dx.doi.org/10.1163/ej.9789004137028.3-756

[13] De Haan, E., Balancing free trade in water and the protection of water resources in GATT. The Scarcity of Water - Emerging Legal and Policy Responses, eds. E.H.P. Brans, et al., Kluwer: The Hague, pp. 246-247, 1997.

[14] Little, S.Ph., Canada's capacity to control the flow: water export and the North American Free Trade Agreement. Pace International Law Review, VIII(1), pp. 127, ff, 1996.

[15] Baumann, C., Water wars: Canada's upstream battle to ban bulk water export. Minnesota Journal of Global Trade, 10(1), pp. 109, ff, 2001. 
[16] Brown Weiss, E., Water transfers and International Trade Law. Fresh Water and International Economic Law, eds. E. Brown Weiss, L. Boisson de Chazournes, N. Bernasconi-Osterwalder, Oxford University Press: Oxford, 2005.

[17] Cossy, M., Water services at the WTO - selected legal issues. Fresh Water and International Economic Law, eds E. Brown Weiss, L. Boisson de Chazournes, N. Bernasconi-Osterwalder, Oxford University Press: Oxford, pp. 117-141, 2005. doi: http://dx.doi.org/10.1093/ bybil/77.1.453

[18] Tuerk, E., Ostrovsky, A. \& Speed, R., GATS and its impact on private sector participation in water services. Fresh Water and International Economic Law, eds. E. Brown Weiss, L. Boisson de Chazournes, N. Bernasconi-Osterwalder, Oxford University Press: Oxford: pp. 143-172, 2005.

[19] Boisson de Chazournes, L., Fresh Water in International Law, Oxford University Press: Oxford, pp. 83-96, 2015. doi: http://dx.doi.org/10.1017/s2044251314000307

[20] Bray, H.L., ICSID and the right to water: an ingredient in the stone soup. ICSID Review, pp. 1-10, 2014. doi: http://dx.doi.org/10.1093/icsidreview/sit055 